\title{
Highbush Blueberry Production Guide
}

Northeast Regional Agricultural Engineering Service, 152 Riley-Robb Hall, Cooperative Extension, Ithaca, NY 148535701

The Highbush Blueberry Production Guide is the first comprehensive resource for new and experienced blueberry growers as well as farm advisers who assist them. The guide covers all aspects ofblueberry production, from preparing the site to marketing the fruit. It includes topics not discussed in other fruit-producing guides, notably nuisance wildlife management, water management, spray technology, and budgeting. The guide also presents descriptions of 61 varieties of southern and northern highbush and halfhigh blueberries, including 24 that have been developed recently in North America, Australia, and New Zealand.

The Highbush Blueberry Production Guide is the work of more than 50 researchers, extension workers, and growers from 17 states. Its editors are Marvin Pritts, associate professor of fruit and vegetable science at Cornell Univ., Ithaca, N.Y., and James Hancock, professor of horticulture at Michigan State Univ., East Lansing. The 200-page guide contains 16 chapters, two appendices, a glossary, a diagnostic key, a table of English-tometric conversion factors, and lists of suggested readings. It is illustrated with 27 tables, 24 drawings and charts, and 168 full-color photographs.

The guide is sold in a 3-ring binder, which allows users to update the text with notes, additional publications, or local recommendations. The cost of the Highbush Blueberry Production Guide is $\$ 45$. Quantity discounts are available. 